\title{
INFLUENCE OF WORKPLACE DESIGN ON EMPLOYEE QUALITY OF WORK IN SELECTED TERTIARY INSTITUTIONS IN LAGOS STATE
}

\author{
DOI: 10.36108/ljerhrm/2202.03.0180
}

\author{
JAYAOBA, Foluso Ilesanmi (PhD), KOLAWOLE, Ibukun Olorunsola (PhD), ADESANYA, \\ Atinuke Regina (PhD Fellow). \\ foluso.jayaoba@lasu.edu.ng, ibukun.kolawole@lasu.edu.ng, atinukeregina@ymail.com \\ Department of Industrial Relations and Human Resource Management, Faculty of Management \\ Sciences, Lagos State University, Ojo
}

\begin{abstract}
This study examined the influence of workplace design on employee quality of work in the selected tertiary institutions in Lagos State. Lecturers, students and other employees have depicted conflicting opinions and reactions as to the physical designs of their workplace and how the designs affect the quality of their work. Personal interview with some staff and students of Lagos State University (LASU) showed that, like other survey in literature, while some believe the workplace design does put the employee into consideration, others, especially the students, feel it affect their performance negatively as their workstation look shameful to them. The study aimed to examine how ergo-friendly workplace designs influence employee work time delivery and if consideration for employees' input in the acquisition of equipment and furniture influence the employee quality of work in selected higher institutions Lagos State. The study adopted a survey research design. The population of the study comprised of academic staff in four tertiary institutions in Lagos State, this result in a total population of two thousand two hundred and eighty (2280). The study used Yamane (1967) formula to derive a sample size of three hundred and fifty (350) from the population. The study adopted a random sampling technique in selecting the sample from the population. The reliability of the research instrument was assessed using the Cronbach's Alpha coefficient while the validity was assessed using content and face validities. The study found that, amongst others, there is a moderate positive relationship between employees' inputs in the acquisition of equipment and employee quality of work $(R=0.608)$; this implies that as the employees' opinions and contributions are sought and utilised, employees' quality of work improves. It was concluded that ergo-friendly workplace designs are essential factors in improving employees work time delivery and, therefore, recommended that management of tertiary institutions should make workplace environment more ergo-friendly as this has shown to have a significant effect on work time delivery of staff.
\end{abstract}

Keywords:Ergo-friendly workplace design, employee quality of work, equipment, work time deliver, workplace design.

\section{Introduction}

Improving the design of the workplace environment is seen by ninety-seven percent $(97 \%)$ of employees interviewed by Management of Today magazine as a sign of how valuable they are to their employer. About thirty-seven percent $(37 \%)$ of these respondents believed their workplace design does put the employee into consideration. While about thirty-three percent (33\%) said, this affects negatively their ability to attend to visitors or client in their office since their workstation look shameful to them(DEGW; The Centre for Building Performance; Diagnostics at Carnegie Mellon University; Arup, 2005). 
This study is based on recent observations by the researcher on the similarities between the survey in the study of DEGW(2005) and observed gap (i.e., deficiencies in type and arrangement of furniture fitting or workstation) and how workplace design influence quality of work output in organisations in Nigeria. This gap can even be observed mainly in the citadels of learning, where lecturers, students and other employees have conflicting opinions and reactions to the physical designs of their workplace environments and effect on the quality of their work. Personal interaction of the researcher with some staff and students of Lagos State University (LASU) showed that, like the survey above, while some believe the workplace design does put the employee into consideration, others, especially the students, feel it affect their performance negatively as their workstation look shameful to them.

The above is a scenario that would bother the management of any progressive system (organisations). These deficiencies observed in the Nigerian academic workplace design needs urgent attention of investigation for the possible effect on the quality of work. Also, despite the enormous amount the management of universities spend to improve the workplace design and furniture (for offices, lecture rooms and research laboratories) during the NUC accreditation exercise, many of the end-users of this redesigned and improved workplace still believed that the resulting work is not ergo-friendly enough (based on the pilot study earlier conducted on some staff and students of LASU). There is a need to investigate the system to determine how the possibly conflicting opinions of the employees that are either directly or indirectly involved 'in the production process' (the process of producing the university graduates and academic research) influence their quality of work. This is because researchers such as Olukunle (2015) have identified that whatever affects morale on the job is likely to affect job commitment and invariably the quality of work.

Past studies (like Johnny \&Nwonu 2014, Kamarulzaman, Saleh, Hashim, Hashim \&bdul-Ghani, 2011;\&Olukunle, 2015 used qualitative approach to study the relationship between the two variables (workplace design and performance) while others that used quantitative approach studied the relationship with workplace design as a single variable against performance as a single variable. This study operationalised the study variables and identified indicators for the study variables Workplace Design and Employee Quality of Work. The extent to which workplace design is ergo friendly and the level of consideration given to employees' input in the acquisition of equipment for their workplace measures the independent variable- Workplace Design.

Due to the general public outcry on the quality of graduate and research output from the Nigeria citadels of learning, this study examined the Employee Quality of Work as a performance variable and identified Employee Work Time Delivery and Employee Quality of Work as indicators to measure it.

\section{Objectives of the Study}

This study aims to examine the relationship between Workplace Design and Employee Quality of Work while the specific objectives of the study are;

1. To examine how ergo-friendly workplace designs influence Employee Work Time Delivery in the selected higher institution in Lagos State. 
2. To examine if consideration for employees' input in the acquisition of equipment and furnitureinfluence the Employee Quality of Work in selected higher institution Lagos State.

\section{Research Questions}

1. How does the ergo-friendly workplace design influence Employee Work Time Delivery in the selected higher institution in Lagos State?

2. What level of consideration given to employees' input in the acquisition of equipment for their workplace influence the Employee Quality of Work in selected higher institution Lagos State?

\section{Research Hypotheses}

1. An ergo-friendly workplace design does not influence Employee Work Time Delivery in the selected higher institution in Lagos State.

2. Consideration for employees' input in the acquisition of equipment does not influence the Employee Quality of Work in the selected higher institution in Lagos State.

\section{Literature Review}

\section{Conceptual Clarifications}

Haworth (2015) research have shown that management of organisations in developed counties especially in Europe have embraced the use of workplace design as an emerging opportunity to express their willingness to improve their employee's safety and health which invariably improve their output. Chauhan (2017), in his online lecture; identified the vital role workplace design plays in maximising the quality of output delivery of employees of any organisation. Chauhan further distinguished from the literature how recent workplace design takes into cognisance the principles of innovation and philosophy of the organisation had become the absolute solution to getting the optimal quality of output from their employees. This is an improvement on the traditional workplace environment identified by Haworth (2015) research but still characterised most organisations in Nigeria, especially the academics environment. In the traditional workplace environment, as explained in Haworth (2015) research, the design-focused is on improving productivity with the psychology to bring the "work only" version into the office. This means the human resources were not considered in space design in the past; instead, the focus was on functional requirements that support the working person: tasks, technology, and processes.

Tajana, Majaand Predrag (2019) are of the opinion that Ergonomics-the science identified with the recent ambition of managers to optimise the efforts of the available human resources in the achievement of organisation objectives, achieve this partly through a design model of the workplace that takes into account the capabilities and limitations of the worker. Thus, making the optimal use of space through improve placement of equipment, recognising the human factor into workplace design, seeking employee's opinion in the workplace design and effectively aligning the workplace into the surrounding environment are identified objectives of workplace design that are ergo-friendly. This is the essence of this study adapting how ergo-friendly the present workplace design is from an employee perspective and the level of consideration given to employees in the acquisition of equipment and furniture for their workplace as indicators for the independent variable-workplace 
design. Tajana et al., (2019)also identified from the literature the robust impact workplace design has on any organisation and the benefits while applying it as:

1.Reduced cost by decreasing injuries occurrence of the workers.

2. Improved productivity is the result of the better-designed workplace, which ensures proper posture, less exertion and fewer motions of the workers.

3. Better quality because poor ergo-friendly design leads to frustrated and fatigued workers that don't do their best at work.

4. If an employee does not experience fatigue and discomfort during their workday, this can result in a decrease of absenteeism, improved morale and increased employee involvement.

5. Better human performance because of safety and health culture created in the organisation.

Workplaces should be designed so that most people can safely and effectively perform the required tasks. Certain criteria need to be taken into consideration while developing and an ergonomic workplace such as reaches, anthropometric size/dimensions, muscle strength/capability and visual capabilities.

Thomas (2012) viewsan ergo-friendly workplace design strives to be effective in fulfilling the functional requirements of users. Such design aims to propagate intuition, teamwork, and more importantly, provide a safe and comfortable environment for quality output delivery. Occupational Safety and Health Academy (OSHA) (2017) opined that he designing of workstations, work practices and workflow to fit the employees' capabilities, enable the reduction in risk factors that may contribute to common work-related injuries and illnesses, such as sprains and strain and cumulative trauma disorders (CTDs). These are common employees' safety issues that occur as a result of accumulated strain on the employee for a period of time (Grainger, Forest, \& Hamilton, 2013). For example, the design of workspaces that make employees work in awkward postures same position/all the time may result in the excessive effort, fatigue and discomfort of the employee. These conditions may cause damage to some of the body components such as muscles, tendons, ligament, nerves and blood vessels. Such injuries are known as musculoskeletal disorders (MSDs) (Occupational Safety \& Health Academy, 2017).

Based on the above, this study adapts the concept as stated in BusinessDictionary (2019)as an arrangement in the workplace that has the objective of overcoming employee alienation and job dissatisfaction that comes about from mechanical and repetitive tasks in the workplace. It is also used by organisations to boost productivity by offering employees non- monetary rewards such as satisfaction from a greater sense of personal achievement. Employee quality of work is a performance measure that isn't just a period evaluation within a system. It is a continuous, positive activity that required adjustments to work performance as needed, and can be assessed and supported to meet the system goals and stakeholders alike. Glass (2019), explaining the concept of 'Employee quality of work'" as a performance measure can be difficult, but a critical examination of views from different perception can give a better understanding. Thompson (2019),employee quality of workhelps to observe how any given employee is performing. It also gives insights into overall problems or gaps with identified project team-i.e. if every employee is doing the same thing poorly, then the root of the problem could be a training issue. John (2017), believed that, employee quality of 
work is the value of work delivered by an individual. This can include the quality of task completion, interactions and deliverables. It is also a common consideration in managing the performance of programs, projects, vendors and individuals.

Chartered Institute of Personnel and Development-CIPD (2017) are of the opinion that, a clear definition of employee quality of work, is not yet forthcoming. Agreeing on what comprises 'good' or 'decent quality' work delivery is part of the challenge. To this study, this is because most literatures such as Svenn-Åge, Torstein, and Karen (2009) focused on 'job quality' as if it has the same concept as 'quality of work' with similar challenges in concept generation. As identified by CIPD, 'quality of work' just like 'job quality' has dimensions that are largely reflected by the disciplinary traditions of the researchers. Lastly, a substantive cost to employers occurs when employees use Work hours to deal with work related stress, health, safety and workplace accidental matters that affect their work time delivery. The use of time on the job to handle these issues results in productivity losses. The International Labour Organisation (2019) also identified that working excessive hours in an uncomfortable environment posed a danger to workers' health and invariably the time to deliver quality work. Though previous research has rarely used employee work time delivery as a factor in measuring performance especially in academics' environment. Thus, for a better understanding of the concept, this study examined related concept from different working environment.

First, Work Time refers to time spend at workplace carrying out duties under the direction of employer(Trades Union Congress, n.d.). Although Kim (2000) categorized work time as positive and negative, any amount of work time used to handle issues related to the job at hand, may be an indicator of lost productivity. Secondly the construct delivery is one of terms mostly used by operations and production personnel especially in the manufacturing sector as a performance measurement. It comes in differs form such as delivery date; due date; on time delivery etc. But, delivery as performance measure can be defined as extent to which products and services from an organisation meet the customer time expectation(Madhusudhana, Prahlada, \& Muniswam, 2011). It provides an indication of the potentiality of the supply chain in providing for the need of a customer. Hence in the term, employee work time delivery in this study is the expected time for an employee to give an acceptable level of output that commiserate the input of the working environment.

\section{Theoretical Framework}

Though several theories were examined, three theories were considered relevant for the study. These theories are; McGregor theory X and theory Y; Maslow's hierarchy of needs theory and Optimizing Human Productivity theory.

\section{McGregorTheory $X$ and Theory $Y$}

Theory $\mathrm{X}$ and Theory Y suggesting two aspects of human behaviour at work, or in other words, two different views of individuals (employees): one of which is negative, called Theory $\mathrm{X}$ and the other is positive, so-called Theory Y. According to McGregor, the perception of managers on the nature of individuals is based on various assumptions. 
Theory $\mathrm{X}$ managers tend to take a pessimistic view of their people, and assume that they are naturally unmotivated and dislike work. As a result, they think that team members need to be prompted, rewardedor punished constantly to make sure that they complete their tasks.

Work in organizations that are managed like this can be repetitive, and people are often motivated with a "carrot and stick" approach. Performance appraisalsandremuneration are usually based on tangible results, such as sales figures or product output, and are used to control staff and "keep tabs" on them.

\section{Assumptions of Theory X}

- An average employee intrinsically does not like work and tries to escape it whenever possible.

- Since the employee does not want to work, he must be compelled, with punishment so as to achieve goals. The managers adopt a more dictatorial style.

- Many employees rank job security on top, and they have little or no aspiration/ ambition.

- Employees generally dislike responsibilities; Employees resist change.

- An average employee needs formal direction.

- Have no incentive to work or ambition, and therefore need to be enticed by rewards to achieve goals.

Theory Y managers have an optimistic, positive opinion of their people, and they use a decentralized, participative management style. This encourages a more collaborative, trust-based relationship between managers and their team members.

People have greater responsibility, and managers encourage them to develop their skills and suggest improvements. Appraisals are regular but, unlike in Theory $\mathrm{X}$ organizations, they are used to encourage open communication rather than control staff.

\section{Assumptions of Theory $\mathbf{Y}$}

- Employees can perceive their job as relaxing and normal. They exercise their physical and mental efforts in an inherent manner in their jobs.

- Employees may not require only threat, external control and coercion to work, but they can use self-direction and self-control if they are dedicated and sincere to achieve the organizational objectives.

- If the job is rewarding and satisfying, then it will result in employees' loyalty and commitment to organization.

- An average employee can learn to admit and recognize the responsibility. In fact, he can even learn to obtain responsibility.

- The employees have skills and capabilities. Their logical capabilities should be fully utilized. In other words, the creativity, resourcefulness and innovative potentiality of the employees can be utilized to solve organizational problems.

Thus, we can say that Theory $\mathrm{X}$ presents a pessimistic view of employees' nature and behaviour at work, while Theory Y presents an optimistic view of the employees' nature and behaviour at work. If correlate it with Maslow's theory, we can say that Theory $\mathrm{X}$ is based on the assumption that the employees emphasized on the physiological needs and the safety needs; while Theory $\mathrm{X}$ is based on 
the assumption that the social needs, esteem needs and the self-actualisation needs dominate the employees. Maslow's hierarchy of needs is a motivational theory in psychology comprising a fivetier model of human needs, often depicted as hierarchical levels within a pyramid. Needs lower down in the hierarchy must be satisfied before individuals can attend to needs higher up. From the bottom of the hierarchy upwards, the needs are physiological, safety or security, love and belonging, esteem, and self-actualisation.

\section{TheoryAforOptimising Human Productivity}

According to Theory A or Theory of Accountability, a proper strategy should be planned in the organisation depending on its objectives and set target. Accountability should be fixed to both individuals and teams in order to ensure success in a given task. The functional elements of Accountability Theory (Theory A) are:

(1) Planning - Institutional assessment, problem identification, and joint policy formulation.

(2) Target setting - Communication, shared understanding, and action planning.

(3) Motivation - Adoption of the idea and increased performance.

(4) Work Strategies - Empowerment, support and team-work.

(5) Responsibility - Commitment, consistency, and target fulfilment.

(6) Role model - Following example and willingness to improve.

(7) Monitoring \& Guiding - Joint review, self-appraisal, and confirmation of accomplishment.

(8) Accountability - Contribution through commitment and creativity.

Though, most workers have been on the same job for most of their employable life because of the reward-salary (as seen in the last assumption of McGregor theory X stated above), the stress, safety and health hazard associated with such job are sometimes high. Despite the fact that Maslow's hierarchy of needs theory identifies security as the second most important need of human, most management of organisations does not pay adequate attention to the safety and stress-free working environment that is desirous of their employee. To most management, an employee should be able to deliver with whatever working environment offered. The management believes an employee should be self-directed to seek responsibility in any environment (as assumed by McGregor theory Y). But this decision of management does have negative impact on workers' morale(Olukunle, 2015). And as identified earlier from the work of Olukunle, 'whatever affects morale on the job is likely to affect job commitment and invariably the quality of work' But based on this study concept of 'Employee quality of work' stated earlier, that shows it as a performance measure in the form of quality of output of the employee, the Optimising Human Productivity theory was adopted.

Optimising Human Performance theory is used to improve individual and group output, reliability, and productivity. What will enhance employee morals towards higher levels of, creativity and fulfilment should be encouraged and supported because of the importance of human resources to any organisation(Sreeramana \& Suresh, 2016). Sreeramana \& Suresh (2016) identified five key elements that the most successful optimising human productivity models have. When appropriately implemented, these elements enable organisations to thrive through the engagement of their employees. These essential elements include (1) Leadership Commitment, (2) Human Capital Planning, (3) Attracting, Developing, and Retaining Employees, (4) Communications Strategy, and (5) Impact Metrics. The optimisation involves designing a system or process to perform as well as 
possible. Even though the performance of human resources in organisations mainly depends on the technology and External environment which substantially impacts organisational behaviour, the way of thinking individually and by teams, and humanistic orientation, which assumes that individual feelings, attitudes, perceptions, goals, etc., are important to the organisation. To that Sreeramana and Suresh,many researchers have tried to optimize productivity using different strategies, including the motivation of employees, privatisation of organisations, optimizing risks and optimizing rewards. This study, examined how the maximize productivity factor- 'Employee quality of work' is affected by workplace design.

\section{Research Methods}

The research design adopted for this study is a descriptive survey. The population of the study comprises of the entire members of academic staff of the citadel of learning selected using judgmental techniques as shown in Table 1 below. The judgmental technique was used based on institutions' proximity and accessibility for the researcher and the field officers.

A sample was drawn from the population using Yamane (1969) which was selected using stratified and purposive sampling techniques (see table 3.1). The sample was stratified to ensure that all the selected institutions were adequately represented, purposive sampling techniques was used to elicit information from those who are willing, relevant to the objectives of the study, and return it within an acceptable time. The sample was divided into each stratum in proportion to the population as shown in the calculation and table below. Data was collected through questionnaire; a five-point Likert Scaled questionnaire was designed to establish how Employee quality of work' is affected by workplace design in Academic environment. Questionnaire were taken to the office and distributed to the staff with minimal persuasion within two weeks. To establish the validity of the research instrument, the study sought opinions of experts in the field of study (content validity). Also, to establish the validity of the research instrument, the study used Cronbach's Alpha methodology, which was based on internal consistency with an initial sample collected. The collected data was analysed using descriptive statistics (frequency table) and inferential statistics (correlation, regression, t-test and multiple regression analyses) with the aid of a statistical software called IBM SPSS (Statistical Product and Service Solution).

Yamane Formula $n=N /\left(1+N(e)^{2}\right)$, Wherenis the sample sizeN is the population size which is $\mathbf{4 6 4 8}$, andeis the level of precision. Taken to be $\mathbf{5 \%}$ in this study. Applying this formula, we get $\mathrm{n}=22820$ / $\left(1+2820(.05)^{2}\right)$

$=2820 /(1+2820(.0025)=\mathbf{3 5 0}$

Table 1: Distribution of Samples in Strata

\begin{tabular}{|l|l|l|l|l|}
\hline \multirow{2}{*}{ S/N } & Institution & Population & Sample \\
\cline { 3 - 5 } & & $\mathbf{N}$ & Source & N \\
\hline $\mathbf{1}$ & Lagos State Polytechnic & 738 & Registry office & 92 \\
\hline $\mathbf{2}$ & Lagos State University & 712 & Registry office & 88 \\
\hline $\mathbf{3}$ & Adeniran Ogunsanya College of Education & 658 & Registry office & 82 \\
\hline $\mathbf{4}$ & Yaba College of Technology & 712 & Registry office & 88 \\
\hline & TOTAL & 2820 & & $\mathbf{3 5 0}$ \\
\hline
\end{tabular}

Source: Researcher, (2019). 


\section{Data Analysis and Discussion of Findings}

\section{Reliability Tests of Each Indicators Using Cronbach's Alpha}

In this section, thereliability of each indicator was tested one after the other using Cronbach's Alpha (SPSS).

\section{Table 2: Reliability Statistics for Work Design}

\section{Reliability Statistics}

Cronbach's $\mathrm{N}$ of Items

Alpha

.791

6

Source: Researcher, 2019.

From the above table, the Cronbach's Alpha has a value of 0.791 . This means that the indicator has $79.1 \%$ reliability, which is highly reliable in testing the hypothesis.

\section{Table 3: Reliability Statistics for Equipment}

\section{Reliability Statistics}

Cronbach's $\mathrm{N}$ of Items

Alpha

$.825 \quad 6$

Source: Researcher, 2019.

From the above table, the Cronbach's Alpha has a value of 0.825 . This means that the indicator has $82.5 \%$ reliability, which is highly reliable in testing the hypothesis.

Table 4: Reliability Statistics for Employee Quality of Work

Reliability Statistics

Cronbach's $\mathrm{N}$ of Items

Alpha

$.802 \quad 6$

Source: Researcher, 2019.

From the above table, the Cronbach's Alpha has a value of 0.802 . This means that the indicator has $80.2 \%$ reliability, which is highly reliable in testing the hypothesis.

\section{Table 5: Reliability Statistics for Fairness}

\section{Reliability Statistics}

Cronbach's $\mathrm{N}$ of Items

\begin{tabular}{cc} 
Alpha \\
\hline .848 \\
\hline
\end{tabular}

Source: Researcher, 2019.

From the above table, the Cronbach's Alpha has a value of 0.848 . This means that the indicator has $84.8 \%$ reliability, which is highly reliable in testing the hypothesis. 


\section{Analysis of Research Hypotheses}

\section{Analysis of Hypothesis One}

$\mathbf{H}_{\mathbf{0}}$ : An ergo-friendly workplace design does not influence Employee Work Time Delivery in the selected higher institution in Lagos State.

Table 6: Result for Hypothesis One

Model Summary

\begin{tabular}{|l|r|r|r|r|r|}
\hline Model & \multicolumn{1}{|c|}{$\mathrm{R}$} & $\mathrm{R}$ Square & $\begin{array}{c}\text { Adjusted R } \\
\text { Square }\end{array}$ & $\begin{array}{c}\text { Std. Error of } \\
\text { the Estimate }\end{array}$ & \multicolumn{1}{c|}{ Sig } \\
\hline 1 & $.694^{\mathrm{a}}$ & .482 & .478 & 4.041 & .000 \\
\hline
\end{tabular}

a. Predictors: (Constant), Workplace Design

Coefficients $^{\mathrm{a}}$

\begin{tabular}{|c|c|c|c|c|c|c|}
\hline \multirow{2}{*}{\multicolumn{2}{|c|}{ Model }} & \multicolumn{2}{|c|}{$\begin{array}{c}\text { Unstandardised } \\
\text { Coefficients }\end{array}$} & \multirow{2}{*}{$\begin{array}{c}\text { Standardised } \\
\text { Coefficients } \\
\text { Beta }\end{array}$} & \multirow[b]{2}{*}{$\mathrm{t}$} & \multirow[b]{2}{*}{ Sig. } \\
\hline & & B & Std. Error & & & \\
\hline 1 & (Constant) & 4.083 & 1.290 & & 3.164 & .002 \\
\hline & $\begin{array}{l}\text { Workplace } \\
\text { Design }\end{array}$ & .778 & .067 & .694 & 11.686 & .000 \\
\hline
\end{tabular}

a. Dependent Variable: Employee Work Time Delivery

Source: Researcher's Computation (2019)

The model summary table above shows that there is a strong positive relationship between ergofriendly workplace design and employee work time delivery $(\mathrm{R}=0.694)$; this implies that as the workplace environment is designed to be more ergo-friendly, employees' work time delivery also improves. The model further shows the extent to which the ergo-friendly workplace design brings about employees' work time delivery among the staff of selected tertiary institutions in Lagos State. The coefficient of determination $\left(\mathrm{R}^{2}=0.482\right)$ shows that the ergo-friendly workplace design explains $48.2 \%$ of the improvement in employees' work time delivery among the staff of selected tertiary institutions in Lagos State. This result is statistically significant because the p-value of the result (0.0001) is less than 0.01 level of significance used for the study. The research hypothesis was rejected. This implies that the ergo-friendly workplace environment influences employees' work time delivery significantly.

Furthermore, an evaluation of the unstandardised coefficientof the ergo-friendly workplace design in the coefficient table and its associated $\mathrm{p}$-value shows that ergo-friendly workplace design $\left(\beta_{\mathrm{WD}}=\right.$ $0.778, \mathrm{p}<0.01)$ is statistically significant and can be used in predicting the work time deliveryamong the staff of LASU. This, therefore, further suggests that the research hypothesis is rejected. This implies that ergo-friendly workplace design has a significant influence on employees' work time delivery.

\section{Analysis of Hypothesis Two}

$\mathbf{H}_{\mathbf{0}}$ : Consideration for employees' input in the acquisition of equipment does not influence the Employee Quality of Work in the selected higher institution in Lagos State. 
Table 7: Result for Hypothesis Two

Model Summary

\begin{tabular}{|l|c|r|r|r|r|}
\hline Model & $\mathrm{R}$ & $\mathrm{R}$ Square & $\begin{array}{c}\text { Adjusted R } \\
\text { Square }\end{array}$ & $\begin{array}{c}\text { Std. Error of } \\
\text { the Estimate }\end{array}$ & \multicolumn{1}{c|}{ Sig } \\
\hline 1 & $.608^{\mathrm{a}}$ & .369 & .365 & 4.087 & .000 \\
\hline
\end{tabular}

a. Predictors: (Constant), Equipment

\section{Coefficients $^{\mathrm{a}}$}

\begin{tabular}{|c|c|c|c|c|c|c|}
\hline \multirow{2}{*}{\multicolumn{2}{|c|}{ Model }} & \multicolumn{2}{|c|}{$\begin{array}{c}\text { Unstandardised } \\
\text { Coefficients }\end{array}$} & \multirow{2}{*}{$\begin{array}{l}\text { Standardised } \\
\text { Coefficients }\end{array}$} & \multirow[b]{2}{*}{$\mathrm{t}$} & \multirow[b]{2}{*}{ Sig. } \\
\hline & & B & Std. Error & & & \\
\hline \multirow[t]{2}{*}{1} & (Constant) & 8.800 & 1.155 & & 7.619 & .000 \\
\hline & Equipment & .571 & .062 & .608 & 9.275 & .000 \\
\hline
\end{tabular}

a. Dependent Variable: Employee Quality of Work

Source: Researcher's Computation (2019)

The model summary table above shows that there is a moderate positive relationship between employees' inputs in the acquisition of equipment and employee quality of work $(\mathrm{R}=0.608)$; this implies that as the employees' opinions and contributions are sought and utilised, employees' quality of work improves. The model also shows the extent to which employees' inputs in the acquisition of equipment bring about employees' quality of work among the staff of selected tertiary institutions in Lagos State. The coefficient of determination $\left(\mathrm{R}^{2}=0.369\right)$ shows that the employees' inputs in the acquisition of equipment account for $36.9 \%$ of the improvement in employees' quality of work among the staff of selected tertiary institutions in Lagos State. This result is statistically significant because the p-value of the result (0.0001) is less than 0.01 level of significance used for the study. The research hypothesis was rejected. This implies that employee' inputs in the acquisition of equipment influence employees' quality of work significantly.

Furthermore, an evaluation of the unstandardizedcoefficientofemployees' inputs in the acquisition of equipment in the coefficient table and its associated p-value shows that employees' inputs in the acquisition of equipment $\left(\beta_{\mathrm{E}}=0.571, \mathrm{p}<0.01\right)$ is statistically significant and can be used in predicting the quality of workamong the selected tertiary institutions in Lagos State. This, therefore, further suggests that the research hypothesis two is rejected. This implies that employees' inputs in the acquisition of equipment havea significant influence on employees' quality of work.

\section{Conclusion}

This study has assessed the impact of workplace design and employee quality of work among the selected tertiary institutions in Lagos State. The results from the survey confirmed that ergo-friendly workplace designs have a positive relationship with employees' work time delivery, and are important factorsin improving employees work time delivery. Comparatively, employees' inputs in 
the acquisition of equipment also have a positive relationship with employee quality of work; this implies as employers and organisations seek opinions and inputs of employees before making purchase decisions on equipment.

\section{References}

Occupatonal Safety and Health Academy (2017). Introduction to ergonomics. OSHA study guide, Retrieved May 15, 2017.

BusinessDictionary. (2019). Work Design. Retrieved April 23, 2019, from WebFinance Inc: http://www.businessdictionary.com/definition/work-design.html

Chartered Institute of Personnel and Development. (2017). Understanding and measuring job quality - Thematic literature review. (W. Chris, W. Sally, \& L. Clare, Editors) Retrieved from https://www.cipd.co.uk/Images/understanding-and-measuring-job-quality-1_tcm1833193.pdf

Chauhan, P. (2017). Workplace Design 101. Retrieved April 23, 2019, from PLEA Website: http://www.morphogenesis.org/media/workplace-design-101/

DEGW; The Centre for Building Performance; Diagnostics at Carnegie Mellon University; Arup. (2005). The Impact of Office Design on BusinessPerformance. British Property Federation, $\mathrm{CABE} / \mathrm{BCO}$ steering committee,. The Commission for Architecture \& the Built Environment and the British Council for Offices. Retrieved May 20, 20119, from https://webarchive.nationalarchives.gov.uk/20110118111511/http://www.cabe.org.uk/files/im pact-office-design-full-research.pdf

Glass, M. (2019). How to Explain Quality of Work on a Performance Review. (Michelle Seidel, Editor) Retrieved June 12, 2019, from https://smallbusiness.chron.com/explain-quality-workperformance-review-20228.html

Grainger, L. F. (2013). Cumulative trauma disorder. the national safety council, Retrieved June 14, 2017.

Haworth. (2015). Workplace Design for Well-being. Retrieved April 23, 2019, from https://www.thercfgroup.com/files/resources/workplace-design-for-well-being.pdf

international Labour Organisation. (2019). Guide to Developing Balanced Working Time Arrangements. (nternational Labour Office • Geneva) Retrieved from https://www.ilo.org/wcmsp5/groups/public/---ed_protect/---protrav/--travail/documents/publication/wcms_706159.pdf

John, S. (2017). 16 Types of Work Quality. Retrieved June 13, 2019, from https://simplicable.com/new/work-quality

Johnny, C. E., and Nwonu, C. O. (2014). A Critical Review of The Effect of Working Conditions On Employee Performance: Evidence From Nigeria.

Kamarulzaman, N., Saleh, A. A., Hashim, S. Z., Hashim, H., Abdul-Ghani, A. A., and . (2011). An Overview of the Influence of Physical Office Environments towards Employees. The 2nd International Building Control Conference 2011 (pp. 262-268). Elsevier-Procedia Engineering. Retrieved April 23, 2019

Madhusudhana, R., Prahlada, R. K., and Muniswam, V. (2011). Delivery Performance Measurement In Anintegrated Supply Chain Management: Case Study Inbatteries Manufacturing Firm. Serbian Journal of Management, 6 (2), 205 - 220. Retrieved from 
http://www.sjm06.com/SJM\%20ISSN1452-4864/6_2_2011_November_123-282/6_2_205220.pdf

Olukunle, S. O. (2015). A Review of Literature on Work Environment and Work Commitment: Implication for Future Research in Citadels of Learning. Journal of Human Resource and Management, 18(2), 32-46. Retrieved from https://www.jhrm.eu/wpcontent/uploads/2015/03/JournalOfHumanResourceMng2015vol18issue2-pages-32-46.pdf

Sreeramana, A., and Suresh, K. P. (2016). Theory A for Optimizing HumanProductivity. Munich Personal RePEc Archive. Retrieved June 13, 2013, from https://mpra.ub.unimuenchen.de/74265/1/MPRA_paper_74265.pdf

Svenn-Åge, D., Torstein, N., and Karen, M. O. (2009). Quality of work-concept and measurement. Edinburgh: RECWOWE Publication, Dissemination and Dialogue Centre,. Retrieved June 13, 2019, from http://www.san.ed.ac.uk/_data/assets/pdf_file/0020/29720/RECWP_0509_Dahl_Nesheim_Olsen.pdf

Tajana, L., Maja, T., and Predrag, Ć. (2019). Ergonomic Design Of Workplace. Retrieved April 28, 2019, from https://bib.irb.hr/datoteka/950195.Ergonomic_Desing_Of_A_Workplace.pdf

Thomas, J. (2012, August 16). Ergonomics and Workplace Design. Retrieved April 23, 2019, from Workplace Design Magazine: https://workdesign.com/2012/08/ergonomics-and-workplacedesign/

Thompson, J. (Ed.). (2019). Performance Appraisal For Quality of Work. (Chron) Retrieved June 13, 2019, from https://smallbusiness.chron.com/performance-appraisal-quality-work-13099.html

Trades Union Congress. (n.d.). Working Time, Breaks and Holidays. (Congress House, Great Russell Street, London WC1B 3LS) Retrieved June 13, 2019, from https://www.tuc.org.uk/sites/default/files/TUC_KYR_Working\%20Time\%2C\%20Breaks\%2 0and\%20Holidays_ART_Low\%20res.pdf 